\title{
SYNTHESIS OF [18F]FLUOROETHOXY-BENZOVESAMICOL, A RADIOTRACER FOR CHOLINERGIC NEURONS
}

\author{
G. Keith Mulholland*, Yong-Woon Jung, Donald M. Wieland, Michael R. Kilboum, \\ and David E. Kuhl
}

Division of Nuclear Medicine, Department of Internal Medicine, University of Michigan Medical Center. 3480 Kresge III, Ann Arbor, Michigan, USA 48109-0552

\section{SUMMARY}

Full experimental details are given for the preparation of $\left[{ }^{18} \mathrm{~F}\right]$ fluoroethoxybenzovesamicol, (-)-(2R,3R)-trans-2-hydroxy-3-(4-phenylpiperidino)-5-(2[18 F]fluoroethoxy)-1,2,3,4-tetralin, a new fluorine-18 labeled cholinergic neuron mapping agent for use in positron emission tomography (PET). This radiotracer was made by nucleophilic radiofluorination of tosyloxyethoxy-benzovesamicol, followed by reverse phase HPLC purification, in decay corrected radiochemical yield exceeding $60 \%$.

Key words: Benzovesamicol, Cholinergic, Fluorine -18, PET, Vesamicol.

\section{INTRODUCTION}

Vesamicol (AH 5183) interacts with the acetylcholine transporter protein on neuronal synaptic vesicles. The concurrence of $\left[{ }^{3} \mathrm{H}\right]$ vesamicol binding sites and cholinergic marker proteins in mammalian brains has led to the suggestion that this compound might serve as a neurochemical marker for cholinergic synaptic function (1-3), and created an interest in radiolabeled variants of vesamicol as imaging agents for in vivo mapping of cholinergic neurons (4-8). The ability to visualize cholinergic function could have important applications in the study of Alzheimer's disease and dysfunctions of the parasympathetic nervous system. A subclass of analogs discovered by Rogers et al., called benzovesamicols, appear to be much more potent and selective than the parent compound (9-12). Several radioiodinated and carbon-11 labeled benzovesamicol analogs have been developed in our laboratories which have favorable in vivo tracer properties $(3,4,13)$. These results suggest this class of compounds holds strong potential for imaging presynaptic cholinergic function in humans.

Fluorine-18 ligands have a number of properties which make them of great interest as imaging agents. They share with ${ }^{11} \mathrm{C}$-agents the ability for high resolution PET imaging and 
quantification; in addition the longer ${ }^{18} \mathrm{~F}$ half life $(110 \mathrm{~min})$ allows for imaging times as late as $8 \mathrm{hr}$ after injection, and permits multiple doses to be dispensed from a single synthesis batch. Furthermore, the very high specific activities $(3-10 \mathrm{Ci} / \mu \mathrm{mol})$ routinely attainable via "no-carrieradded" (nca) nucleophilic ${ }^{18} \mathrm{~F}$ labeling methods provides a greater margin of safety in comparison to ${ }^{11} \mathrm{C}$ when applying toxic compounds like vesamicol as radiotracers. Several ${ }^{18} \mathrm{~F}$-labeled vesamicol and benzovesamicol analogs have been investigated previously $(7,14)$, but there continues to be a need for an analog with optimal tracer properties that is also easily synthesized for clinical investigation.

Here is described the preparation and chemical characteristics of a new fluorine-18 analog fluoroethoxybenzovesamicol (FEOBV, 1) which we feel meets these criteria. Preliminary biological evaluation of FEOBV has been encouraging in both terms of its cholinergic localization and robust tissue uptake characteristics (15). These studies are

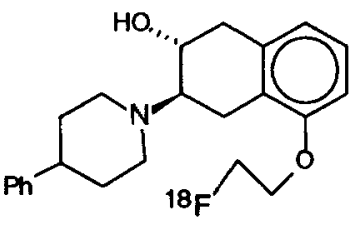

FEOBV (1) ongoing and full characterization of this promising agent in animals is the subject of future communications.

\section{RESULTS AND DISCUSSION}

The synthetic paths for $\left[^{\mathbf{1 8}} \mathbf{F}\right]-1$, authentic 1 , precursors and side products are summarized in Scheme 1. Synthesis of the enantiomeric forms of 1 utilized the pure $(-)$ or $(+)$ isomers of $\mathbf{3}$ as starting materials, which had been resolved by the route shown in Scheme 2.

While numerous [ ${ }^{18} \mathrm{~F}$ ]fluoroethyl amines and amides have been prepared for investigation as PET tracers (19-29), no analogous [ $\left.{ }^{18} \mathrm{~F}\right]$ fluoroethyl ethers have been reported until very recently (31). The approach to $\left.{ }^{18} \mathbf{F}\right]-1$ initially tried was adapted from the "two-step" procedure frequently used for labeling of $\mathrm{N}$ atoms with the $\left[{ }^{18} \mathrm{~F}\right]$ fluoroethyl group. It involved first the formation of $\left[{ }^{18} \mathrm{~F}\right]$ fluoroethyl tosylate $\left(\left[{ }^{18} \mathrm{~F}\right] \mathrm{FET}\right)$ from ethylene glycol ditosylate (TET) by a standard procedure (30), followed by in situ reaction with 4 (Scheme 1, route c.). Although the two-step approach did afford the desired product $\left[{ }^{18} \mathbf{F}\right]-1$, it required the use of at least twice the stoichiometric amount of 4 relative to TET/[ ${ }^{18}$ F]FET to obtain an acceptable labeling yield of 1. This route was wasteful of $\mathbf{4}$, a precious chiral precursor prepared in a multistep sequence involving diazotization of resolved 3 (Schemes 1 and 2.). Another problem was that large amounts of non-radioactive side products were formed that complicated purification of $\left[{ }^{18} \mathbf{F}\right]-1$.

The side products were characterized in an effort to improve yields, and serendipitously, one of these was found to be tosyloxyethyoxybenzovesamicol 2. A test labeling reaction of 2 was tried under standard conditions (nca $\left[{ }^{18} \mathrm{~F}\right]$ fluoride ion $/ \mathrm{K}_{2} \mathrm{CO}_{3} / \mathrm{kryptofix}$ in hot acetonitrile, Scheme 1, route d.) We were pleased to find that $\left.{ }^{18} \mathbf{F}\right]-1$ was formed as the sole radiolabeled product. [18 F]Fluorination was fast; HPLC assay of reactions indicated labeling was complete within 3-7 $\min$ at a heating block temperature of $120^{\circ}$. Compound 2 is a crystalline substance (mp $164^{\circ}$ ) indefinitely stable under refrigeration as the free base. It is readily obtainable on a preparative scale by reacting the phenoxide salt of 4 with excess TET ( Scheme1, route b.). 
<smiles>Nc1cccc2c1CC(N1CCC(c3ccccc3)CC1)[C@H](O)C2</smiles>

a.<smiles>Oc1cccc2c1CC(N1CCC(c3ccccc3)CC1)[C@H](O)C2</smiles>

b.

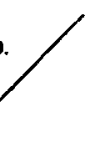<smiles>[18OH]CCC=[TeH4]</smiles><smiles>OCCOc1cccc2c1CC(N1CCC(c3ccccc3)CC1)[C@@H](O)C2</smiles>

2<smiles>[R8]CCCOc1cccc2c1C[C@@H](N1CCC(c3ccccc3)CC1)[C@@H](O)C2</smiles>

1<smiles>CC(C)C1CCN(C2Cc3c(cccc3OCCO)C[C@H]2O)CC1</smiles>

$\mathbf{5}$

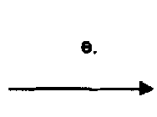

Scheme 1. a. $\mathrm{NaNO}_{2}, \mathrm{H}_{2} \mathrm{SO}_{4} ;$ b. TBAOH, TET; c. FET, base; d. $\left[{ }^{18} \mathrm{~F}\right] \mathrm{F}-/ \mathrm{K}_{2} \mathrm{CO}_{3} / \mathrm{kryptofix}-$ 222. e. $0.2 \mathrm{~N} \mathrm{NaOH}, 3: 1: 1: \mathrm{CH}_{3} \mathrm{CN}: \mathrm{MeOH}: \mathrm{H}_{2} \mathrm{O}$ reflux.

This combination of properties makes 2 an ideal precursor for a reliable "one-step" synthesis of [18F]-1. Each synthesis requires only a small quantity of 2 (0.7-1.5 mg, $1.5-3$ $\mu \mathrm{mol}$ ). Chromatographic purification of $\left[{ }^{18} \mathrm{~F}\right]-1$ is straightforward due to the lower mobility of 2, and the incorporation of a small C-18 extraction column and aqueous rinse cycle into the injection loop of the preparative HPLC simplifies sample loading and removes water soluble materials and kryptofix prior to HPLC injection. The average yield for the most recent 8 runs is $61 \pm 12 \%$, with the end-of-synthesis radioactive amounts in the range of $9-76 \mathrm{mCi}$.

Analysis of reaction by-products indicates that oxygen nucleophiles present in the medium compete with fluoride ion for displacement of the tosylate function of 2 under standard labeling conditions. This observation has seldom been made explicitly in reported examples of $\mathrm{N}$-ethyl tosylate radiofluorination although it undoubtedly occurs to a significant extent in those cases as well. Indeed, the primary (unlabeled) product in the one step labeling reaction is hydroxyethyl compound 5, which presumably results from attack of the tosylate by traces of $\mathrm{OH}^{-}$or $\mathrm{CO}_{3}{ }^{-2}$ made soluble by the kryptofix. Deliberate hydrolysis of 2 in 3:1:1 $\mathrm{CH}_{3} \mathrm{CN}: \mathrm{MeOH}: \mathrm{H}_{2} \mathrm{O}$ containing $0.2 \mathrm{~N}$ $\mathrm{NaOH}$ quickly produces 5 , and surprisingly, a nearly equivalent amount of methoxyethyl 6 due to attack by methanol. These side products are of concern because of the toxicity of this general class of compounds (9). Formation of 5 during the labeling reaction can be lessened, though not avoided completely, by reducing the quantity of $\mathrm{K}_{2} \mathrm{CO}_{3}$ to the absolute minimum- $\sim 4 \mu \mathrm{mol}$ in our experience. Fortunately 5 is substantially more polar than $\left[{ }^{18} \mathbf{F}\right]-1$, and it is efficiently removed during HPLC purification. 
In conclusion, a simple and efficient synthesis of the promising new cholinergic imaging agent FEOBV in high purity has been developed. This method uses a stable, chiral precursor and conventional solution phase nucleophilic labeling techniques, and is amenable to large scale production ( $>50 \mathrm{mCi}$ ) of this agent using commercially available "black box" automated synthesis units with minor modifications.<smiles>Nc1cccc2c1CC(N1CCC(c3ccccc3)CC1)C(O)C2</smiles>

$( \pm)-3$

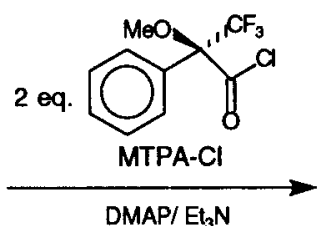

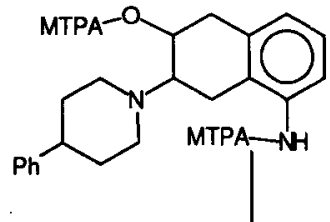

1. separation 2. DIBAL

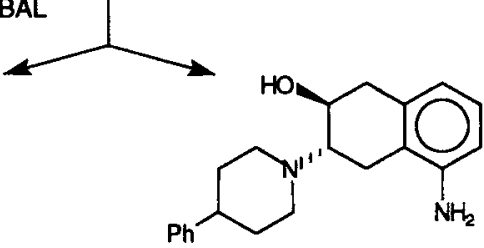

$(+)-(2 S, 3 S)-3$

$(-)-(2 R, 3 R)-3$

$[\alpha]_{D}^{23}=-58.1^{\circ}$

$[\alpha]_{D}^{23}=+54.1^{\circ}$

Scheme 2. Resolution of enantiomers of aminobenzovesamicol 3.

\section{EXPERIMENTAL}

${ }_{1} \mathrm{H}$ NMR spectra were obtained in $\mathrm{CDCl}_{3}$ on a Bruker $360-\mathrm{MHz}$ NMR spectrometer and are reported in parts per million downfield from tetramethylsilane. ${ }^{13} \mathrm{C}$ NMR spectra were measured at $90.56 \mathrm{MHz}$. Mass spectra were obtained in the electron impact (EI) ionization mode at $70 \mathrm{eV}$. Molecular masses are given in atomic mass units, followed by percent intensity relative to the most abundant ion. Accurate mass spectral determinations were also obtained in the EI mode at $70 \mathrm{eV}$. Elemental analyses were carried out by Spang Microanalytical Laboratory, Eagle Harbor, MI. Melting points were determined on a MEL-TEMP apparatus, and are uncorrected. Flash chromatography utilized Merck 230-400 mesh silica gel. Thin-layer chromatography (TLC) used Analtech $0.25 \mathrm{~mm}$ glass-backed plates with fluorescent indicator. Tetrabutyl ammonium hydroxide, (TBAOH, 1M, in methanol), ethylene glycol ditosylate and dry acetonitrile (Sure-Seal) were obtained from Aldrich Chemical Co. and used without further treatment. [ ${ }^{18} \mathrm{FI}$ ]Fluoride ion was made by $17 \mathrm{MeV}$ proton irradiation of $\left[{ }^{18} \mathrm{O}_{\mathrm{H}} \mathrm{O}\right.$ in a silver target (16), and was either used directly or purified prior to use by a silylation procedure described previously (17).

Resolution of ( \pm )-5-aminobenzovesamicol, (3).

Enantiomers of 3 were resolved by flash chromatography of the diastereomeric bis-N,O(S)-(-)- $\alpha$-methoxy- $\alpha$-trifluoromethylphenylacetyl (MTPA) derivatives (18), followed by reductive 
cleavage of the MTPA groups. To a solution of ( \pm )-3 (9) $(1.94 \mathrm{~g}, 6.02 \mathrm{mmol})$, 4dimethylaminopyridine (441 mg, $3.61 \mathrm{mmol})$, triethylamine $(3.36 \mathrm{~mL}, 24.1 \mathrm{mmol})$ in dry $\mathrm{CHCl}_{3}$ $(15 \mathrm{~mL})$ was added dropwise via syringe (S)-(-)-MTPA chloride $(3.49 \mathrm{~g}, 13.84 \mathrm{mmol}$ ) at room temperature. The resulting solution was stirred for 6 hours and then poured into ethyl acetate (30 $\mathrm{mL})$. The solution was washed with saturated $\mathrm{NaHCO}_{3}$ solution $(30 \mathrm{~mL})$ and the aqueous layers were extracted with ethyl acetate $(2 \times 30 \mathrm{~mL})$. The combined extracts were dried over anhydrous $\mathrm{Na}_{2} \mathrm{SO}_{4}$ and concentrated under reduced pressure. The two diastereomeric N,O-bis-MTPA isomers were separated by flash column chromatography on silica using EtOAc: $\mathrm{CH}_{2} \mathrm{Cl}_{2}$ : hexane 1:2:7. The less polar compound ( $\mathrm{Rf}=0.25$, EtOAc: $\mathrm{CH}_{2} \mathrm{Cl}_{2}$ : hexane 1:2:7, silica gel) was (+)$(\mathrm{S}, \mathrm{S})$-bis-MTPA-diastereoisomer. It was isolated in $99 \%$ yield $(2.25 \mathrm{~g})$. The more polar compound ( $\mathrm{Rf}=0.14,1: 2: 7$ EtOAc: $\mathrm{CH}_{2} \mathrm{Cl}_{2}$ :hexane, silica gel), was the (-)-(R,R)diastereoisomer. It was obtained in a yield of $2.23 \mathrm{~g}(98 \%)$.

The (-)-(R,R)-bis-MTPA-diastereoisomer $(2.20 \mathrm{~g}, 2.92 \mathrm{mmol})$ was dissolved in dry toluene $(30 \mathrm{~mL})$ and cooled to $-78^{\circ} \mathrm{C}$. Diisobutyl aluminum hydride $(11.7 \mathrm{~mL}$ of $1.0 \mathrm{M}$ solution in cyclohexane, $11.7 \mathrm{mmol}$ ) was added dropwise via syringe. The resulting solution was stirred at $-78^{\circ} \mathrm{C}$ for $30 \mathrm{~min}$. and allowed to warm to room temperature. The reaction was quenched with 2.5 $\mathrm{N} \mathrm{HCl}(30 \mathrm{~mL})$. The aqueous layers were separated, made alkaline $(\mathrm{pH}=10)$ with $3.0 \mathrm{~N} \mathrm{NaOH}$ solution and extracted with $\mathrm{CH}_{2} \mathrm{Cl}_{2}(3 \times 50 \mathrm{~mL})$. The organic extracts were dried over anhydrous $\mathrm{Na}_{2} \mathrm{SO}_{4}$ and concentrated under reduced pressure. The residue was flash-chromatographed on silica gel with $50 \%$ EtOAc in hexane to afford $880 \mathrm{mg}(94 \%)$ of $(-)-(R, R)-3\left([\alpha]_{D}{ }^{23}=-58.1\right.$, $\mathrm{C}=1.5, \mathrm{EtOH}) . \quad(+)-(\mathrm{R}, \mathrm{R})-3$ was obtained in $90 \%$ yield from the (+)-bis)-MTPA diastereomer using the same procedure as above $\left([\alpha]_{D}{ }^{23}=+54.7, \mathrm{C}=1.5, \mathrm{EtOH}\right)$. Enatiomeric purities of $(-)-$ and $(+)$-enantiomers were $>99 \%$ as determined by chiral HPLC using a Chiracel OD column $(4.6 \mathrm{x}$ $250 \mathrm{~mm}$ ) with a 2-propanol/hexane/Et2NH (50:50:1) mobile phase at a flow rate of $1 \mathrm{~mL} / \mathrm{min}$ and UV detection at $254 \mathrm{~mm}$. Retention times of (+)- and (-)-3 enantiomers were 8.25 and $9.44 \mathrm{~min}$, respectively.

(-)-(2R,3R)-Trans--2-hydroxy-3-(4-phenylpiperidino)-5-hydroxytetralin, (-)-5hydroxybenzovesamicol, (-)HOBV, (4).

Diazotization of (-)-3. To a solution of concentrated sulfuric acid $(2 \mathrm{~mL})$ and water $(4 \mathrm{~mL})$ was added a solution of $(-)-3(150 \mathrm{mg}, 465 \mu \mathrm{mol})$ in THF $(3 \mathrm{~mL})$. The resulting solution was cooled to $5^{\circ} \mathrm{C}$ and a solution of sodium nitrite $(38.5 \mathrm{mg}, 558 \mu \mathrm{mol})$ in water was added dropwise while the temperature of the solution was maintained below $7^{\circ} \mathrm{C}$. The diazonium solution was stirred for 1 hour and added dropwise to a second solution of $\mathrm{H}_{2} \mathrm{SO}_{4}(2 \mathrm{~mL})$ and water $(10 \mathrm{~mL})$ which was heated to boiling. The mixture was boiled for $5 \mathrm{~min}$ after the additions were completed and then allowed to cool to room temperature. The solution was brought to $\mathrm{pH} 9$ with $10 \mathrm{~N} \mathrm{NaOH}$ solution and extracted with ethyl acetate $(3 \times 40 \mathrm{~mL})$. The combined extracts were dried over anhydrous $\mathrm{Na}_{2} \mathrm{SO}_{4}$ and concentrated under reduced pressure. The residue was flashchromatographed on silica with $30 \%$ ethylacetate in hexane to afford (-)-4 after evaporation, as a tan solid, mp 216,$(68 \mathrm{mg}, 45 \%)$. ${ }^{1} \mathrm{H}$ NMR $\left(\mathrm{CDCl}_{3}\right): \delta 1.71-1.95(\mathrm{~m}, 4 \mathrm{H}), 2.43-2.65(\mathrm{~m}, 3 \mathrm{H})$, $2.78-3.08(\mathrm{~m}, 6 \mathrm{H}), 3.30(\mathrm{dd}, \mathrm{J}=16.1,5.6 \mathrm{~Hz}, 1 \mathrm{H}), 3.99(\mathrm{ddd}, \mathrm{J}=16.1,10.4,5.6 \mathrm{~Hz}, 1 \mathrm{H}$ ) 
5.03(br.s, OH), 6.62(d, J=7.9 Hz, 1H), 6.71(d, J=7.6 Hz, 1H), 7.02(t, J=7.8 Hz, 1H), 7.19-

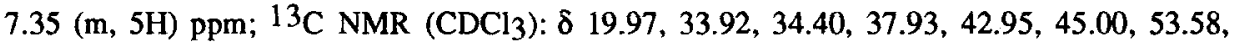
$65.49,66.56,112.15,121.52,121.93,126.23,126.82,126.89,128.46,135.85,146.09$, $153.72 \mathrm{ppm} ; \mathrm{MS}(\mathrm{EI}, 70 \mathrm{eV}) \mathrm{m} / \mathrm{z}$ (relative intensity) 323(61.54, $\left.\mathrm{M}^{+}\right), 306(4.31), 174(100.00)$, 162(26.25), 160(24.67), 145(12.19), 131(13.32); High Resolution MS (EI, $70 \mathrm{eV}$ ): Calcd. for $\mathrm{C}_{21} \mathrm{H}_{25} \mathrm{NO}_{2}$ 323.1885, Found 323.1892; Anal. Calcd for $\mathrm{C}_{21} \mathrm{H}_{25} \mathrm{NO}_{2}$ : C,77.99; $\mathrm{H}, 7.79$; $\mathrm{N}, 4.33$. Found: $C, 77.81 ; H, 7.74 ; N, 4.36$. The $(+)$ isomer of 4 was prepared similarly from $(+)-3$ in $40 \%$ yield. It had identical analytical data to (-)-4, including melting point. Racemic 4 had a mp of $208-210^{\circ} \mathrm{C}$.

\section{(-)-(2R,3R)-trans--2-hydroxy-3-(4-phenylpiperidino)-5-(2-tosyloxethoxy)- tetralin, (-)-5-(2-tosyloxyethoxy)-benzovesamicol, (-)TEOBV, (2).}

A solution of (-)-HOBV $4(5 \mathrm{mg}, 15.5 \mu \mathrm{mol})$ and TBAOH $(17 \mu \mathrm{mol}, 17 \mu \mathrm{L}$ of a $1 \mathrm{M}$ solution in $\mathrm{MeOH}$ ) in $2 \mathrm{~mL}$ of acetonitrile was evaporated to dryness on a rotary evaporator at room temperature, and then dry acetonitrile $(1 \mathrm{~mL})$ was added to the residue and the mixture was re-evaporated to remove traces of moisture. Ethylene glycol ditosylate $(74 \mathrm{mg}, 200 \mu \mathrm{mol})$ and 2 $\mathrm{mL}$ of acetonitrile were added to the residue and and the reaction mixture was warmed at $60-70^{\circ}$ for $2 \mathrm{hr}$, or until.all HOBV had disappeared, as measured by analytical reverse phase HPLC (column: 5 micron silica C-18, mobile phase: $1.5 \mathrm{~mL} / \mathrm{min}, 3: 1: 1 \mathrm{CH}_{3} \mathrm{CN}$ : $\mathrm{MeOH}: 20 \mathrm{mM} \mathrm{KHPO} 4, \mathrm{pH}$

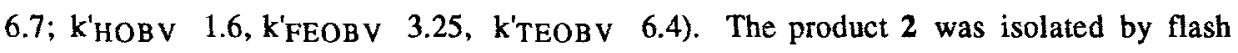
chromatography on silica using a hexane: $\mathrm{Et}_{2} \mathrm{O}$ step gradient to give, after crystallization from iPrOH, $5.6 \mathrm{mg}(69 \%)$ of white crystals of (-)TEOBV 2 , mp $164-166^{\circ} \mathrm{C}$. The $(+)$ isomer was prepared in identical fashion from (+)HOBV. It had a melting point of $165-166^{\circ}$. Racemic 2 had a melting point of $157^{\circ} \mathrm{C}$. ${ }^{1} \mathrm{H}$ NMR $\left(\mathrm{CDCl}_{3}\right): \delta 1.65-1.97(\mathrm{~m}, 4 \mathrm{H}), 2.45(\mathrm{~s}, 3 \mathrm{H}), 2.48-2.68(\mathrm{~m}$, $3 \mathrm{H}), 2.75-3.09(\mathrm{~m}, 6 \mathrm{H}), 3.28(\mathrm{dd}, \mathrm{J}=15.9,5.6 \mathrm{~Hz}, 1 \mathrm{H}), 3.85(\mathrm{td}, \mathrm{J}=10.2,5.6 \mathrm{~Hz}, 1 \mathrm{H}), 4.18(\mathrm{td}$, $\mathrm{J}=4.7,2.3 \mathrm{~Hz}, 2 \mathrm{H}), 4.41(\mathrm{t}, \mathrm{J}=4.7 \mathrm{~Hz}, 2 \mathrm{H}), 6.56(\mathrm{~d}, \mathrm{~J}=7.8 \mathrm{~Hz}, 1 \mathrm{H}), 6.75(\mathrm{~d}, \mathrm{~J}=7.8 \mathrm{~Hz}, 1 \mathrm{H})$, $7.07(\mathrm{t}, \mathrm{J}=7.8 \mathrm{~Hz}, 1 \mathrm{H}), 7.16-7.36(\mathrm{~m}, 7 \mathrm{H}), 7.82(\mathrm{~d}, \mathrm{~J}=8.4 \mathrm{~Hz}, 2 \mathrm{H}) \mathrm{ppm}$.; MS (EI, 70eV): $\mathrm{m} / \mathrm{z}$ (relative intensity) 521(M+, 26.1), 385(20.4), 372(8.0), 350(48.4), 323(9.2), 279(5.3), 213(5.7), 212(3.8), 203(5.2), 199(12.2), 174(50.6), 167(10.7), 160(11.6), 149(27.7), 57(100); High Resolution MS (EI $70 \mathrm{eV}$ ): Calcd. for $\mathrm{C}_{30} \mathrm{H}_{35} \mathrm{NO}_{5} \mathrm{~S}$ 521.2236, found: 521.2245; Anal. calcd for $\mathrm{C}_{30} \mathrm{H}_{35} \mathrm{NO}_{5} \mathrm{~S}$ : C,69.07; H,6.76; N, 2.68. Found: C, 69.25; H, 6.69; N, 2.60 .

\section{(-)-(2R,3R)-Trans--2-hydroxy-3-(4-phenylpiperidino)-5-(2-fluoroethoxy)-}

tetralin, (-)-5-(2-fluoroethoxy)-benzovesamicol, FEOBV, (1).

A solution of (-)-HOBV $4(60 \mathrm{mg}, 186 \mu \mathrm{mol})$ was dissolved in $3 \mathrm{~mL}$ of $\mathrm{CH}_{2} \mathrm{Cl}_{2}$ under inert atmosphere and $200 \mu \mathrm{L}$ of $1 \mathrm{M} \mathrm{TBAOH}$ in $\mathrm{MeOH}$ was added. The solvent was removed by rotary evaporation at room temperature. To the residue was added $2 \mathrm{~mL}$ of dry $\mathrm{CH}_{3} \mathrm{CN}$ which was then evaporated to azeotropically remove traces of moisture. This step was repeated once. The residue containing the dark phenoxide salt was resuspended in a fresh $3.5 \mathrm{~mL}$ portion of $\mathrm{CH}_{3} \mathrm{CN}$ and 2-fluoroethyl tosylate $(50 \mathrm{mg}, 230 \mu \mathrm{mol})$ was added. The mixture was heated (inert atrmosphere) at $70-80^{\circ}$ for $2 \mathrm{hr}$, or until the the consumption of HOBV was complete, as measured by HPLC. Following evaporation of reaction solvent, the crude product was partitoned between 
$\mathrm{CH}_{2} \mathrm{Cl}_{2}$ and water, and the $\mathrm{CH}_{2} \mathrm{Cl}_{2}$ layer was washed with $0.5 \mathrm{~N} \mathrm{NaOH}$, dried $\left(\mathrm{Na}_{2} \mathrm{SO}_{4}\right)$, and concentrated to an oil, which was purified by flash chromatography (hexane:EtOAc). The yield of final product (-)-1 (white crystals, mp 149-150 , from $\mathrm{MeOH}$ ) was $53 \mathrm{mg}(77 \%) .{ }^{1} \mathrm{H}$ NMR $\left(\mathrm{CDCl}_{3}\right): \delta$ 1.72-1.94(m, $\left.4 \mathrm{H}\right), 2.46-2.65(\mathrm{~m}, 3 \mathrm{H}), 2.74-3.02(\mathrm{~m}, 5 \mathrm{H}), 3.10(\mathrm{dd}, \mathrm{J}=16.7,5.0 \mathrm{~Hz}$,

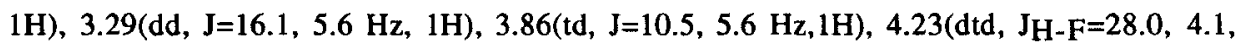

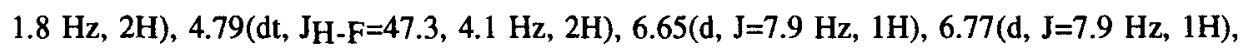
7.11(t, J=7.9 Hz, $1 \mathrm{H}), 7.18-7.35(\mathrm{~m}, 5 \mathrm{H}) \mathrm{ppm}$; $\mathrm{MS}(\mathrm{EI}, 70 \mathrm{eV}) \mathrm{m} / \mathrm{z}$ (relative intensity) $369\left(\mathrm{M}^{+}\right.$, 26.14), 322(2.99), 219(6.56), 208(3.27), 203(7.53), 202(7.88), 191(7.21), 186(4.46), 179(5.82), 174(100.00), 172(20.95), 162(15.58), 160(17.47), 146(8.39), 131(19.55), 115(22.00), 103(15.90), 91(31.74); High Resolution MS (EI $70 \mathrm{eV}$ ): Calcd. for $\mathrm{C}_{23} \mathrm{H}_{28} \mathrm{FNO}_{2}$ 369.2104, Found 369.2101; Anal. calcd. for $\mathrm{C}_{23} \mathrm{H}_{28} \mathrm{FNO}_{2}$ : C,74.77; $\mathrm{H}, 7.64 ; \mathrm{N}, 3.79$. Found: C, $74.79 ; \mathrm{H}, 7.60 ; \mathrm{N}, 3.90$.

\section{(-)-(2R,3R)-Trans--2-hydroxy-3-(4-phenylpiperidino)-5-(2-[18F]fluoroethoxy)- tetralin, (-)-5-(2-[18 F]fluoroethoxy)-benzovesamicol, [18F]FEOBV, ([18F]-1).} To an azeotropically dried $\mathrm{CH}_{3} \mathrm{CN}$ solution of nca [ ${ }^{18}$ F] fluoride ion, $\mathrm{K}_{2} \mathrm{CO}_{3}(1.04 \mathrm{mg}$, $7.5 \mu \mathrm{mol})$, and kryptofix $222(6 \mathrm{mg}, 16 \mu \mathrm{mol})$ was added $2(0.7-1.5 \mathrm{mg}, 1.5-3 \mu \mathrm{mol})$. The mixture ( $1 \mathrm{~mL}$ total solution volume) was heated at $110-120^{\circ}$ for $6-10 \mathrm{~min}$ in a septum-sealed, magnetically stirred pyrex "V-vial". The reaction solution was diluted 1:1 with water and passed through a C-18 silica (Fisher, $150 \mathrm{mg}$ ) solid-phase extraction column mounted on a HPLC injection valve in the "Load" position. The cartridge was washed with water $(3 \times 1 \mathrm{~mL})$ and then was switched to the "Inject" position to elute the retained crude [18 $\mathbf{F}]-1$ with HPLC solvent onto a preparative HPLC column for purification. Conditions: C-18 10 micron, $10 \times 250 \mathrm{~mm}$ column; mobile phase 65: 15: $25 \mathrm{CH}_{3} \mathrm{CN}: \mathrm{MeOH}: 10 \mathrm{mM} \mathrm{KHPO} 4$, pH 6.7, $4 \mathrm{~mL} / \mathrm{min}$. [18 ${ }^{18}$ ]-1 eluted at 12-13.5 min, separated from 2 (18 $\mathrm{min}$ ), and a non-radioactive polar material ( Rt 6-8 min, compound 5, see below). After adding 2 drops of glacial acetic acid to the product fraction, the solvent was removed by rotary evaporation at $60^{\circ} \mathrm{C}$. The final product [ ${ }^{18} \mathrm{~F}$ ]-1 was formulated in saline containing $2.5 \%$ ethanol for intravascular injection. The specific activity exceeded 2000 $\mathrm{Ci} / \mathrm{mmol}$ with $99 \%$ radiochemical purity at end of synthesis, as indicated by analytical reverse phase HPLC (column: 5 micron C-18 silica, mobile phase: $1.5 \mathrm{~mL} / \mathrm{min}, 3: 1: 1 \mathrm{CH}_{3} \mathrm{CN}$ : $\mathrm{MeOH}$ : $20 \mathrm{mM} \mathrm{KHPO} 4, \mathrm{pH} 6.7$, with serial UV $220 \mathrm{~nm}$ and gamma radioactivity $\left(\mathrm{CaF}_{2}\right)$ detectors); $\mathrm{k}_{\text {FEOBV }}^{\prime} 3.25, \mathrm{k}_{\text {TEOBV }}^{\prime} 6.4 ., \mathrm{k}_{5}^{\prime}$ 1.45. The apparent lower limit for quantification of 1 under routine conditions was $500 \mathrm{ng} / \mathrm{mL}$ of formulated solution. The overall time of synthesis beginning with [ ${ }^{18}$ F]fluoride solution was $50-70 \mathrm{~min}$ and the decay corrected yields ranged from $44-81 \%$.

The polar non-radioactive by-product 5 (prep HPLC retention 6-8 min, analytical HPLC $\left.\mathbf{k}^{\prime}=1.45\right)$ was isolated from pooled labeling reactions, and identified as $(-)-(2 \mathbf{R}, 3 \mathbf{R})$-trans--2hydroxy-3-(4-phenylpiperidino)-5-(2-hydroxyethoxy)-tetralin, (-)-5-(2-hydroxyethoxy)-benzovesamicol, on the basis of mass spectral analysis. MS (EI, $70 \mathrm{eV}) . \mathrm{m} / \mathrm{z}$ (relative intensity): 367(100, $\mathrm{M}^{+}$), 350(10, $\left.\mathrm{M}-\mathrm{OH}\right), 323(12), 322\left(14, \mathrm{M}-\mathrm{CH}_{2} \mathrm{CH}_{2} \mathrm{OH}\right), 315(20)$, 301(23), 227(14), 217(16), 175(10), 174(44), 172(12), 160(11), 149(20), 144(12), 114(12), 71(15), 57(22), 56(15), 55(11.8) 45(16), 43(18), 41(12). High Resolution MS (EI $70 \mathrm{eV}$ ): Calcd. for $\mathrm{C}_{23} \mathrm{H}_{29} \mathrm{NO}_{3} 367.2147$, Found 367.2135 . The same material was produced when 2 
$(\sim 1 \mathrm{mg}, 2 \mu \mathrm{mol})$ was refluxed $0.2 \mathrm{~N} \mathrm{NaOH}$ in $3: 1: 1 \mathrm{CH}_{3} \mathrm{CN}: \mathrm{MeOH}: \mathrm{H}_{2} \mathrm{O}$. Complete disappearance of 2 occured in $40 \mathrm{~min}$.

A second, less polar compound was also formed from 2 under these test solvolysis conditions, in yield equivalent, by UV detector integration, to the amount of 5 produced. The amount of this second product isolated by HPLC was sufficient only for characterization by MS. (EI, 70eV) $\mathrm{m} / \mathrm{z}$ (relative intensity): 381(100, $\mathrm{M}^{+}$), 350(20), 323(20), 322(19), 227(25), 200(25), 174(63), 133(22) 89(40), 69(20), 59(27), 45(75). Accurate mass for molecular ion (381.2326) gave a formula of $\mathrm{C}_{24} \mathrm{H}_{31} \mathrm{NO}_{3}$ (predicted: 381.2304 ) which corresponds to replacement of the tosylate group in 2 with a methoxy group. The assigned structure was (-)-(2R,3R)-trans--2hydroxy-3-(4-phenylpiperidino)-5-(2-methoxyethoxy)-tetralin, (-)-5-(2-methoxyethoxy)-benzovesamicol, (6).

\section{ACKNOWLEDGEMENTS}

The authors thank Dr. David Gildersleeve for his efforts in analyzing the enantiomeric purity of compounds described herein. This work was supported by the following sources: National Institutes of Health grants 5 RO1 NS24896, 2 RO1 NS25656, 2 PO1 NS15655, and Department of Energy grant DEFG-02-87ER60561.

\section{REFERENCES}

1. Marien M.R., Parsons S.M. and Altar C. A. - Proc. Natl. Acad. Sci. USA 84: 876 (1987)

2. Marshall I.G., Parsons S. M. - TINS 10:174, (1987)

3. Altar C.A., Marien M.R. - Synapse 2: 486 (1988)

4. Jung Y-W., Van Dort M.E., Gildersleeve D.L. and Wieland D.M. - J. Med. Chem. 33: 2065 (1990)

5. Kilbourn M.-R., Jung Y.-W., Haka M.S., Gildersleeve D. L., Kuhl D. E., Wieland D. M. - Life Sci. 47:1955 (1990)

6. Efange S.M.N., Dutta A.K., Michelson R.H., Kung H.F., Thomas J.R., Billings J. and Boudreau R.J. - Nucl. Med. Biol. 19: 337 (1992)

7. a. Widen L., Eriksson L., Ingvar M., Parsons S.M., Rogers G.A. and Stone-Elander S. Neurosci. Ltr. 136: 1 (1992). b. Rogers G.A., Stone-Elander S,. Erikssson L., IngvarM., Parsons S., Widen L.- J Labelled. Cmpds. Radiopharm. 32:486 (1993).

8. Mulholland G.K. and Jung Y.-W. - J. Labelled Cmpds. Radiopharm. 31: 253 (1992)

9. Rogers G.A., Parsons S.M., Anderson D.C., Nilsson L.M., Bahr B.A., Kornreich W.D., Kaufman R., Jacobs R.S. and Kirtman B. - J. Med. Chem. 32: 1217 (1989)

10. Rogers G.A. and Parsons S.M. - NeuroReport 1: 11 (1990)

11. Hicks B. W., Rogers G. A., Parsons S. M. - J. Neurochem. 57: $509-519$ (1991).

12. Rogers G. A., Kornreich W. D., Hand K., Parsons S. M. - Soc. Neuroscience Abstr. 18:1358, P569.20 (1992)

13. Mulholland GK, Sherman PS, Pisani TL, Kilbourn MR, Kuhl DE. - J. Cereb. Blood. Flow Metab. 11:S622, 1991. 
14. Mulholland G. K., Buck F., Sherman P. S., Pisani T. L., Jung Y-W., Frey K. A., Kuhl, D. E., Kilbourn M. R. - J. Nucl. Med. 32:P994 (1991)

15. Mulholland GK, Jung Y-W, Sherman PS, Pisani TL, Kuhl DE, Wieland DM, Kilbourn MR. - J Labelled. Cmpds. Radiopharm. 32:487 (1993).

16. Mulholland GK, Hichwa RD, Kilbourn MR, Moskwa J. - J Labelled. Cmpds. Radiopharm. 26:192 (1989).

17. Mulholland GK. - Appl. Radiat. Isot. 42:1003 (1991).

18. Dale J. A., Dull D. L., Mosher H. S. - J. Org. Chem. 34:2543 (1969).

19. Satymurthy N, Bida GT, Barrio JR, et al., - Nucl. Med. Biol. 13:617 (1986).

20. Keisewetter DO, EckelmanWC, Cohen RM et al., - Appl. Radiat. Isot. 37:1181 (1986).

21. Block D., Coenen H.H., Stocklin G. J. - J. Labelled Cmpds. Radiopharm. 23:1042 (1986).

22. Jerabek P.A., Patrick T.B., Kilbourn M.R., Dischino D.D, and Welch M.J. - Appl. Radiat. Isot. 37: 599 (1986).

23. Chi DY, Kilbourn MR, Katzenellenbogen JA, Brodack JW, Welch MJ. - J. Labelled Cmpds. Radiopharm. 23:1034 (1986).

24. Shuie CY, Bai LQ, Teng R, Wolf A. - J. Labelled Cmpds. Radiopharm. 23:1037 (1986).

25. Kiesewetter D.O., Brucke T. and Finn R.D. - Appl. Radiat. Isot. 40: 455 (1989).

26. Lemaire C., Damhaut P., Cantineau R., Plenevaux A. and Guillaume M. - J. Labelled Cmpds. Radiopharm. 30: 374 (1991).

27. Plenevaux A., Cantineau R., Labar D., Lemaire C. and Guillaume M. - J. Labelled Cmpds Radiopharm. 30: 382 (1991).

28. Suehiro M., Wilson A.A., Scheffel U., Dannals R.F., Ravert H.T. and Wagner Jr H.N. Nucl. Med. Biol. 18: 791 (1991).

29. Moerlein S.M., Perlmutter J.S. and Parkinson D. - J. Labelled Cmpds. Radiopharm.32:316 (1993).

30. Block D., Coenen H.H. and Stocklin G. - J Labelled Cmpds. Radiopharm. 24: 1029 (1987).

31. French A.N., Napolitano E., VanBrocklin H.F., Hanson R.N., Welch M.J. and Katzenellenbogen J.A. - Nucl. Med. Biol 20:31-47 (1993). 